\title{
The Radical Poetry of Claude McKay
}

\author{
Prof. Mohamed Elsaid Alkon \\ Prof of English Literature \\ Department of English \\ Faculty of Education \\ Ain Shams University
}

\author{
Dr. Mona Salah El Din Hassanein \\ Lecturer in English Literature \\ Department of English \\ Faculty of Education \\ Ain Shams University
}

\author{
Submitted by \\ Amira Ezz El Din Ahmed Abd Allah \\ Department of English, \\ Faculty of Education, \\ Ain Shams University
}

\begin{abstract}
Claude McKay is one of the forerunners of the Harlem Renaissance movement which emerged in the 1920s and continued through the 1930s. He is best known for his radical poetry. He represents the spokesman of black people. His poetry refers to revolutionary black identity. His racial poetry centers mainly on radicalism. When one explores what McKay introduces in his poetry, one discovers his attitude towards violence, revolution, resistance and rebellion against the immense persecution and racism in America. By closely examining several examples of McKay's racial poems, this study attempts to demonstrate how he utilizes poetry to "urge the multitude toward the brink / of freer worlds" (McKay's "We Who Revolt" Complete Poems 208-209). Adopting the sociological approach, the study examines the poems in their cultural, political and societal context in order to shed light on the position of the black community in the American society and illuminate the conflicts between blacks and whites in America at the times of the poems' composition.
\end{abstract}




\section{The Radical Poetry of Claude McKay}

\author{
Prof. Mohamed Elsaid Alkon \\ Prof of English Literature \\ Department of English \\ Faculty of Education \\ Ain Shams University
}

\author{
Dr. Mona Salah El Din Hassanein \\ Lecturer in English Literature \\ Department of English \\ Faculty of Education \\ Ain Shams University
}

\section{Submitted by \\ Amira Ezz El Din Ahmed Abd Allah \\ Department of English, \\ Faculty of Education, \\ Ain Shams University}

The main objectives of this research paper are to highlight the pivotal role of Claude McKay as a revolutionary figure of the Harlem Renaissance (1920s-1930s) and to show how McKay affirms the revolutionary black identity in his poetry. Another objective is also to trace how his radical poetry inspires Afro-Americans to revolt fiercely against racial segregation with its concomitant sufferings and problems which include marginalization, alienation, dehumanization, victimization and lynching committed against them at the hands of whites in America. This research also displays how McKay urges the black people to attain their liberation not in a peaceful way, but in a vehement revolutionary manner. It also shows his attitude towards black violence, resistance, revolution and rebellion against racial persecution in the American society.

The main argument in this research is that radicalism constitutes a recurrent theme in McKay's poetry, as exemplified by his poems "Like a Strong Tree," "To the White Fiends," "If We Must Die," "We Who revolt," "Battle," "America," "The White City," "The Night Fire," "The White House," and "The New Forces". Central to McKay's treatment of this pivotal theme are the role of poetry and condemnation of racism. The role of poetry as a powerful energy to change the status quo is exemplified by his poems "Poetry" and "To a Poet". His drastic rejection of racial discrimination is exemplified by his racial poems "Enslaved," "The Lynching," "Harlem Shadows," "The Barrier," "Birds of Prey" and "Outcast", aiming to make social and political transformation as well as radical change in America. These poems are selected because they are the best ones which reveal his radical expressions and themes. The 
radical poetry of McKay is underscored simply because it represents a distinctive attitude during the cultural and literary movement "the Harlem Renaissance," a fact which has necessitated the adoption of the sociological approach in this research.

Adopting the sociological approach, the researcher examines the poems in their cultural, political and societal context in order to shed light on the position of the black community in the American society at large and illuminate the conflicts between blacks and whites in America at the times of the poems' composition. The concept of ideology is also used in my critical readings of the text. The paper examines the examples of McKay's poems to demonstrate the way in which he uses poetry to motivate blacks to revolt against injustice and inequality committed against them in the American society.

Claude McKay (1890-1948) is one of the key figures of the Harlem Renaissance movement. Jones states that McKay represents the global and international perspective of the Harlem Renaissance (200). In the introduction to McKay's autobiography A Long Way From Home, Jarrett claims that Alain Locke characterizes McKay as the dean of the Harlem Renaissance and as a promising youth of New Negro modernism (xvii). Chauhan claims that McKay ought to be read as a pioneer of this movement (22).

The Harlem Renaissance is a cultural, literary and intellectual movement in the twentieth century (1920s-1930s). In The Concise Oxford Dictionary of Literary Terms (1990), Chris Baldick defines the Harlem Renaissance as a notable phase of the African American writing centered in Harlem. It refers to a new self- awareness and critical respect to black literature in the United States (96). The Harlem Renaissance is one of the most influential movements in Afro-American literary history and an early manifestation of black consciousness in America. It represents the flourishing of Afro-American literature, art and culture. It denotes the new Afro-American cultural expression and a rebirth of African American arts. Sometimes, this movement is referred to as the Negro Renaissance.

The Negro Renaissance includes many poets such as Claude McKay, Langston Hughes, Countee Cullen, James Weldon Johnson, Jean Toomer, Alice Dunbar-Nelson, Helene Johnson, Georgia Douglas Johnson and Angelina Weld Grimke. The Harlem Renaissance poets dealt in their poems with topics pertaining to the African American community such as identity, culture, history, race, heritage, class and gender. McKay is a distinctive poet because he focuses fundamentally on 
racial issues. A major feature of McKay's racial poetry is the emphasis he places on radicalism as a means to change the status quo of AfroAmericans who suffered a long history of discrimination in America. Some other Harlem poets refuse to center on racial politics. For instance, Countee Cullen doesn't want to be a black poet, he wants to be remembered as a lyric poet. Besides, Harlem female poets focus mainly on black womanhood and women problems.

When the Harlem Renaissance was in vogue, its advocates adopted two different attitudes: peaceful coexistence or violent resistance. For example, Langston Hughes called for gaining the African rights of freedom, equality and liberation in a peaceful, soft and calm way. On the contrary, Claude McKay asserted that violence ought to be encountered with violence. McKay called for violent black revolutionary resistance against persecution in order to obtain independence and liberty. McKay was a radical figure of the Harlem Renaissance.

As a major contributor to the Harlem Renaissance, Claude McKay wrote poems that dramatize the internal exile of black Westerners and urges blacks to revolt against racially motivated injustice and oppression. In the introduction to A Long Way From Home, Jarrett states that McKay is one of the most sophisticated black writers of the first half of the twentieth century. His poems and their realistic portrayal demonstrate his profound connection to Afro-American identity and issues of race (xxii). In his poetry, he seeks to affirm revolutionary black identity; he asks his black people to be active, positive, struggling for change and questing for rights. He encourages them to make radical changes in the current social and political conditions. Fredrick W. Hickling states that McKay must be seen as a black revolutionary poet who derives his power from his peasant origins in the hills of Clarendon. His poetry is an important instrument of militant struggle. He forces black people to place themselves in the context of race and class, leads them to a cultural interpretation of life, and encourages them to apply the principles of liberation (29).

Some critics describe McKay as a social radical poet; he is defiant in his protest poetry. In the introduction to McKay's Complete Poems, William Maxwell describes McKay as "the most radical instigator of Harlem's cultural rebirth" and as "the gallant bomb-thrower of black poetry, appreciated by an improbable alliance of revolutionaries and sonnet fanciers (xvi-xvii). Paola Boi characterizes McKay as the most fiery, powerful and radical poet in Harlem's artistic world (in Wintz and Finkleman 66). Smith claims that the rebellious philosophy in McKay's poems traces back through his turbulent youth and his affiliation with 
radical organizations and black people (273). In his autobiography $A$ Long Way From Home, McKay clarifies that the essence of his message is that revolution for blacks must be focused on African American ideology with black institutions and organizations and great black leaders (354).

Born in Jamaica under British colonial rule, McKay experienced racial injustice in his homeland before immigrating to USA and Europe. In spite of McKay's living and being educated in a colonial society, he never felt any sense of inferiority and he never doubted the beauty of his blackness. In his autobiography, McKay writes that it had been his intention to celebrate in his writings "purely physical pride of a black person resolute in being himself and yet living a simple civilized life..."(6). McKay's upbringing in Jamaican colonial society shaped him in profound ways. He became aware of color prejudice and refused racial inequality. He also feels sympathy for the oppressed blacks and attempts to give voice to their plight. Thus, he uses the power of art to bring about change, inciting blacks to revolt against racism.

McKay started wandering from one place to another to escape from racial segregation, poverty, death and harshness of life, seeking to find a place full of joy, happiness, peace, justice, equality, freedom and racial liberation. He came to USA in 1912. In America, he was shocked by the intense racism which inspired him to write rebellious poetry. It was the first time for McKay to have firsthand experience of racial discrimination in America. In his article "Claude McKay Describes His Own Life: A Negro Poet," McKay says "It was the first time I had ever come face to face with such manifest, implacable hate of my race.... I had heard of prejudice in America but never dreamed of it being so intensity bitter,....there is....prejudice rooted in class distinction-color and race being hardly taken into account"(275). In 1914, McKay went to Harlem where he enthusiastically continued writing poetry. For McKay, Harlem was a spiritual home and a source of literary inspiration. As Jarrett points out, it represented a "psychic and emotional point of reference" (xx).

Through the early 1920s, McKay spent 12 years wandering through Europe, North Africa and Soviet Russia. In 1921, he went to Russia to inspect the Russian revolution and participated in the world communist movement. Hickling mentions that McKay's visit to Soviet Union was to measure the black revolution with the yardstick of the Russian achievement. McKay became the darling of the Russian people and rubbed shoulders with the leaders of Russian revolution (27). Upon his return to the United States in 1921, he published his best known collection of poems Harlem Shadows. This book took its name from the 
title of the poem "Harlem Shadows." Most of McKay's racial poems were published in this collection of poetry. The book speaks about a persecuted race and shows sorrow, hatred and resentment for the Western civilization. David Goldweber writes that with the publication of Harlem Shadows, McKay became known as the most vociferous and fiery black poet (11). Robert A. Smith describes the book as a direct blast for white policy of discrimination (271).

McKay also became an executive editor of the Liberator, a major white magazine, during this period. After McKay's appearance in the Liberator, he entered more fully into the literary world. Maxwell presents the Liberator's claim that McKay is "the foremost revolutionary poet" of the 1920s (qtd. in introduction to Complete Poems xxiv). McKay associated with the larger literary world; he relied firstly on white magazines such as the Liberator, Seven Arts and Pearson's. Cooper states that most black writers of the twentieth century depended on black publications, while McKay's first successes were in white publications. He was the only black writer to hold such position on an important American publication (305).

McKay is a leading voice for black awakening to the devastating effects of racism in white American society. He is best known for his angry militant poetic style. Chauhan describes McKay's poetry as "radical", a manifesto of negritude and as part of protest literature of the 1920s (in Mcleod 22).Maxwell states that James Weldon Johnson describes McKay as "the most powerful voice in post-war black poetry and one of the principal forces in bringing about the Negro literary awakening" (qtd. in introduction to Complete Poems xxi). Maxwell adds that most of McKay's poetry shows the whole world to be a chastely political creature, concentrating on platforms against color and class injury (xxv).

McKay's tremendous role as a revolutionary black messenger or a great modern black leader centers on black people and black artists. He feels not only the importance of the black intellectuals, but also the necessity of all individuals of black community for the flourishing of the New Negro movement. As Raynor points out, McKay feels that true racial uplift, progress and racial consciousness depend on all segments of black community and educated black elite (in Wintz and Finkelman 72). McKay asks the black artists to be liberated from the chains of racial segregation. In his article "For A Negro Magazine" (1934), McKay says 
"We want to encourage Negroes to create artistically as an ethnological group....We want to help the Negro as writer and artist to free his mind of the shackles imposed upon it from outside." Then, McKay also articulates the standards for the creative black artist: sincerity of purpose, adequate form of expression and freshness of perception which demonstrate the arduous life of African American people (in Huggins 403). The role of poetry and the black artists from McKay's viewpoint is revealed in his poems "Poetry" and "To a Poet"

McKay believes in the power of poetry as a means of changing the status quo and social as well as political transformation. He explores this theme in his sonnet "Poetry" (1922) (Complete Poems 179). The poet is addressing poetry in this sonnet. Poetry is described as a powerful force and as a "blazing light"; the image of light is particularly significant as it suggests the association of poetry with enlightenment, illumination and knowledge. Poetry is capable of highlighting the voice of African tribulation, aiming to make drastic fundamental reforms: "And seek to hide my tortured soul from thee, / Bowing my head in deep humility / Before the silent thunder of thy power. / Sometimes I flee thy blazing light," (11.2-5). The speaker is afraid of poetry's "magic cup" in which his love, joy and passion might be lost. There is a sense of self-sacrifice in the final couplet:

For oh , I fear they will be swallowed up-

The loves which are to me of vital worth,

My passion and my pleasure in the earth-

And lost forever in thy magic cup!

I fear, I fear my truly human heart

Will perish on the altar-stone of art! (11. 9-14)

McKay inspires other black artists to write radical poetry because it gives them high social status. In "To a Poet" (1922) (Complete Poems 179-180), McKay shows a high fame, glory and reputability of a poet in a society: "There is a lovely noise about your name, / Above the shoutings of the city clear, / More than a moment's merriment, whose claim / Will greater grow with every mellowed year," (11. 1-4). People will remember his words which record their history and express aspects of their life. They will even dance to the beautiful rhythm of his words. The notes to the poem in Complete Poems comment on the lines 5-6 ("the people will not bear you down the street, / Dancing to the strong rhythm of your words,"), saying that ironically McKay "was hoisted onto shoulders of a crowd and carried down a Moscow boulevard" within 
months of the publication of Harlem Shadows (333). The lines 7-8 ("The modern kings will throttle you to greet/ The piping voice of artificial birds") criticize the patrons who want to silence the voice of protest and encourage instead the writers of traditional lyrics.

In order to encourage his black people to rebel, McKay is increasing their awareness of racial discrimination. The message McKay wants to deliver is to "forge through art a new social and political awareness" (Helbling 51). McKay realizes the importance of racial consciousness for the black people. They have to pursue their cultural roots and to assert their own identity in order to liberate themselves from dependence and enslavement. In his various writings, McKay affirms his disdain for racism and bigotry in a white racist society. Hickling proclaims that blacks struggled to find a collective identity and a collective unity in those harsh colonial times, when segregation and lynching existed in America (25). McKay's condemnation of racial segregation is revealed in his poems "Enslaved," "The Lynching," "Harlem Shadows," "The Barrier," "Birds of Prey" and "Outcast".

McKay recounts a long history of enslavement, showing that black folks do not deserve to be slaves. So they have to rebel against this unfair system of slavery. He shows his sympathy for the blacks who suffered throughout history and justifies his commitment to the plight of the blacks. McKay's sonnet "Enslaved"(1921) (Complete Poems 167) says that the black people suffered not only in the West but also in the countries of their birth where they were disinherited and robbed. Smith explains that "Enslaved" traces the ills and suffering of the black race during its sojourn in several lands. It is not a poem of acquiescence or submission. It is a voice conscious of persecution, that dares to strike back with vehemence (271-272). The title represents Afro-Americans' long way of sufferance from enslavement. The persona reminds the audience of many centuries of pain, sorrow and hardship when African slaves were persecuted, suppressed, tortured, murdered and deprived of their human rights by an oppressive white power. Furthermore, the black slaves become "disinherited" of their homeland; the speaker uses a metaphor comparing the white racists to fiendish beasts which "robbed" African's land of birth:

Oh, when I think of my long-suffering race,

For weary centuries despised, oppressed,

Enslaved and lynched, denied a human place 
In the great life line of the Christian West;

And in the black land disinherited,

Robbed in the ancient country of its birth (11. 1-6)

Then, McKay weeps and screams for his homeless race. He feels gloominess, melancholy and frustration as a result of yoke, discrimination and animosity toward his black race: "My heart grows sick with hate, becomes as lead, / For this my race that has no home on earth. / Then from the dark depths of my soul I cry." (11. 7-9). McKay shows his anger and his profound desire to avenge for the sins committed against his people. Complete annihilation of the white world is what the poet desires:

To the avenging angel to consume

The white man's world of wonders utterly:

Let it be swallowed up in earth's vast womb,

Or upward roll as sacrificial smoke

To liberate my people from its yoke! (11.10-14)

McKay condemns the violent act of lynching committed against blacks, he urges Afro-Americans to be powerful to encounter this violent deed. Lynching is one of the cruel acts of violence that blacks suffered at the hands of whites. It is an extralegal execution especially by hanging or shooting directed at blacks. It occurred in the United States chiefly from the late $19^{\text {th }}$ century through the 1960s. McKay's sonnet "The Lynching"(1920) (Complete Poems 176-77) portrays the event of a black man being lynched, highlighting the gruesome acts of violence and racialism committed against blacks in America during the twentieth century. The poem opens with the ascension of the black victim's "spirit" in the air to his heavenly father. The rising of the "smoke" of the charred body implies the atrocious crime of burning till death by an angry white mob: "His spirit in smoke ascended to high heaven. / His father, by the cruelest way of pain, / Had bidden him to his bosom once again;" (11. 13 ). There is no forgiveness by God for those who practiced the brutal lynching because the white lynchers feel no regret and guilt for their criminal deeds: "The awful sin remained still unforgiven." (1. 4)

The corpse of the hanged black man remains till day dawned in order to evoke fear, worry and horror inside the hearts of other blacks. The white crowds, males, females and children, are gathered together viewing this terrifying scene happily. The white women's eyes are made of steel, suggesting absence of feelings of sympathy. A chilling image of children dancing with sadistic pleasure around the dead man shows the 
transferring of cruelty, ignorance and vehemence to the future generations of whites and displays the anger for the coming generations of blacks in America. Throughout the whole poem, the narrator utilizes enjambments to draw the reader's attention to the severity of extra-legal executions practiced against blacks:

Hung pitifully o'er the swinging char.

Day dawned, and soon the mixed crowds came to view

The ghastly body swaying in the sun

The women thronged to look, but never a one

Showed sorrow in her eyes of steely blue;

And little lads, lynchers that were to be,

Danced round the dreadful thing in fiendish glee. (11. 8-14)

In the American society, blacks suffered from discrimination in different fields of life such as a higher rate of poverty and unemployment. McKay rejects the fact that some Afro-American women were forced by poverty to work as prostitutes. The American community looks at a black female as a cheap commodity; she works as a whore; this shameful deed portrays how America despises and demeans African women. McKay exclaims how black men are satisfied with their black women being insulted, so they have to drastically refuse African female prostitution. McKay deals with the plight of black female prostitution in American society in his poem "Harlem Shadows" (1918) (Complete Poems 161-62). Chauhan states that the narrator of "Harlem Shadows" is the rueful patriarch bemoaning the corruption of the lawless dark prostitutes (in Mcleod 29). The first lines convey the desperation and sadness of young black girls resorting to whoredom to survive. Their footsteps are described as "halting" denoting their resentment and anger at this degrading work: "I hear the halting footsteps of a lass / In Negro Harlem when the night lets fall / Its veil. I see the shapes of girls who pass" (1l. 1-3). The speaker utilizes alliteration which stresses the submissive acts of the dark girls who are forced to "bend and barter". McKay creates influential images of "night" and "day", black and white, signifying discrimination against black females: "Through the long night until the silver break / Of day the little gray feet know no rest;" (11. 7-8). Their poverty has forced them to walk in the way of vice and deterioration. The white world is personified as it has "pushed" them to work as women of night. The black race is described as "fallen"; blacks have been exploited by whites. The refined adjective "weary" refers to 
the physical and spiritual tiredness of the Harlem prostitutes due to the ethnic distinction:

Ah, stern harsh world, that in the wretched way

Of poverty, dishonor and disgrace,

Has pushed the timid little feet of clay,

The sacred brown feet of my fallen race!

$\mathrm{Ah}$, heart of me, the weary, weary feet

In Harlem wandering from street to street. (11. 13-18)

In America, blacks were looked down upon as inferiors. They have to resist such immense persecution. McKay displays the plight of interracial marriage which was prohibited during the time he wrote his poem "The Barrier" (1919) (Complete Poems157). The poem reflects aspects of the culture of the American society especially the relation between blacks and whites as two opposing groups in society. The speaker is in love with a white woman but it is forbidden to have a relation with her because of the barrier of race. He compares the "eyes" of his white beloved to "dawning day" showing how she is so pretty, beautiful and enchanting. She is also compared to the "sun" denoting that her whiteness makes her have a bright future and an easy way to success in America. On the contrary, her lover must go a dark and hard path because of his blackness. The repetition of "must not" asserts the impossibility of the completion of this love: "I must not watch you as you go / Your sun-illumined way;" (11. 3-4)

The apparent difference between the two lovers is the complexion of their skin. The fact that she is white and he is black is the only reason keeping them separated. The racial barrier prevents them from being together. Their love transcends the social norms and is not accepted in the American society. So, the "spark" of their great love must be turned off:

I must not see upon your face

Love's softly glowing spark;

For there's the barrier of race,

You're fair and I am dark. (11. 9-12)

McKay portrays the vehemence, cruelty and sadism of white people, asking black masses to refuse this ill treatment and to confront violence with extreme violence. He shows brutality and monstrosity of murdering Afro-Americans at the hands of the white racists in his sonnet "Birds of 
Prey" (1920) (Complete Poems 174-75). The whole poem is an extended metaphor comparing whites to birds of prey and blacks to victims. The poem opens with the coming of birds of prey which is accompanied with the shadow of darkness; this image denotes that white injustice overshadows justice: "Their shadow dims the sunshine of our days, / As they go lumbering across the sky," (11. 1-2). Those predatory birds are ready to attack with an extraordinary power. But before their onslaught, they spread horror, terror and fear inside the hearts of their victims in order that they can easily kill blacks with little efforts: "Beating their heavy wings of owlish gray. / They scare the singing birds of earth away" (11. 4-5). Blacks are described as hard workers (toilers) so they committed no crime which would justify the fierce attacks by whites. This means that white oppression against blacks is utterly unjustified.

McKay visualizes a dreadful picture of killing black masses without pity or mercy. The fatal raptors "swoop" for their victims and "fasten" their sharp talons in the bodies of their victims making them submissive for their fated death. They catch them strongly so that the preys have nothing to do to stop this gruesome murder and have no choice to flee from their hunters. Then the predatory birds grasp and tear apart their victims without "pause". The blood becomes everywhere. With sadistic gladness, they chew the "hearts" of prey and swallow them. This bloody scene shows how the white people are savage, vehement and ruthless and how they enjoy murdering and torturing black people:

They swoop down for the spoil in certain might, And fasten in our bleeding flesh their claws.

They beat us to surrender weak with fright, And tugging and tearing without let or pause, They flap their hideous wings in grim delight, And stuff our gory hearts into maws. (11. 9-14)

In America, the black people felt that they were alienated, marginalized and second-class citizens. McKay shows that blacks cannot feel they are American citizen having the same equal rights of the white masses without fierce rebellion. He displays his profound and distressing sense of alienation and loss in racist America in his sonnet "Outcast" (1922) (Complete Poems173-74). The symbolism of the title shows that blacks are not part of the American society; they are rejected and neglected in the Western world. So they have desires to return back to Africa where they were born and their ancestors lived. The speaker's soul 
"longs" for his homeland Africa: "For the dim regions whence my fathers came / My spirit, bondaged by the body, longs." (11. 1-2). The personification of his spirit as it sings "jungle songs" expresses his hopeless longing and eagerness. The lines 6-8 convey a sense of imprisonment and suffocation as the speaker, who represents blacks, is compared to some kind of property which is possessed by whites:

But the great western world holds me in fee,

And I may never hope for full release

While to its alien gods I bend my knee (11. 6-8)

The speaker is enslaved by white America. His body in one place (America) while his spirit longs for another (Africa); his sense of divided self: the body versus the soul echoes the ideas of Du Bois in The Souls of Black Folks that the black man feels his "twoness, an American and Negro: two souls in one dark body" (9). McKay says "Something in me is lost, forever lost," (1. 9). The modal verb "must" shows the inner conflict he suffers from and his ambivalent feelings toward America; he hates it but at the same time he "must walk the way of life" in it .The speaker is forced to live as a "ghost" being lost in the Western civilization. He is alone and homeless; he is far away from his "native" land Africa and is ruled and dominated by mean discriminatory white society. He never feels a sense of belonging to white America:

Among the sons of earth, a thing apart;

For I was born, far from my native clime

Under the white man's menace, out of time. (11. 12-14)

According to McKay, black radicalism can liberate his oppressed black people. His poetry becomes radical, expressing his militant opposition to racism. He challenges white authority in America. In the preface to Constab Ballads, McKay writes "I.... rebelled; but the rebellion was in my heart.... to relieve my feelings, I wrote poems and into them I poured my heart in various moods" (7). In the introduction to Complete Poems, Maxwell states that the deciding battle of McKay's poetry was the struggle to produce faithful lyric poetry of modern cataclysm (xxxix). McKay directs his protest at racist oppression. His poems display his fierce hatred of injustice. In A Long Way From Home, he says that when a black person makes an honorable fight for a decent living and succeeds, all black people should feel proud (91). 
Radicalism denotes the attempt to effect a thorough and complete change. This can entail the use of violence, protest, and the resort to defiance and militancy. It is revealed in his poems: "Like a Strong Tree," "To the White Fiends," "If We Must Die," "We Who revolt," "Battle," "America," "The White City," "The Night Fire," "The White House," and "The New Forces".

McKay urges the suppressed black masses to be resistant and persistent and to stand courageously in the face of the color bar. $\mathrm{He}$ explains the reasons why he encourages blacks to revolt against whites. McKay's sonnet "Like a Strong Tree" (1925) (Complete Poems 209) discusses McKay's call for his fellow blacks to rebel against white racism. Helbling states that "Like a Strong Tree" expresses McKay's sense of anguish as well as his defiance which sprang from the unmitigated horror he felt when confronted with American racism (51). The poem opens with a simile comparing the speaker as a spokesman of his black people to "a strong tree" which spreads "its roots" in "the virgin earth"; it denotes Afro-Americans' stability, steadfastness and persistence to fight through the "rock and loam and clay" of segregation, violence and restrictive laws aiming at getting rid of all these horrific conditions. The speaker lives in an imperial society :

Like a strong tree that reaches down, deep, deep

For sunken water, fluid underground,

Where the great-ringed unsightly blind worms creep,

And queer things of the nether world abound:

So would I live in rich imperial growth

Touching the surface and the depth of things (11. 5-10).

Living in America, the rich capitalist society, has some advantages but it has its drawbacks, hence the poet uses the two images of "sweet" and "stings". McKay says:

Tasting the sweets of being and the stings, Sensing the subtle spell of changing forms, Like a strong tree against a thousand storms. (11. 12-14)

The message McKay wants to deliver is that he urges his black fellows to commit vehement bloody acts against their white foes in order to gain their rights of equality and freedom."To the White Fiends" 
(1918) (Complete Poems 132-33) is a sonnet which displays McKay's threat of severe challenge against the white "savage[s]". Cooper states that this poem presents a personality unaccustomed to servility and murderously aroused against the brutish debasement of racial prejudice (299). The poem opens with a rhetorical question, showing the black people's ability to commit terrible criminal deeds like the white fiends. The blacks can also direct vehemence and barbarity toward their white foes: "Think ye I am not fiend and savage too? (1. 1). The speaker threatens with the bloodshed of the white persecutors. The black crowds will be armed by several weapons in order to murder infinite numbers of the whites; they will revenge for their African brothers who were killed, tortured till death, "burnt" and lynched by the mean whites:

Think ye I could not arm me with a gun

And shoot down ten of you for everyone

Of my black brothers murdered, burnt by you?

Be not deceived, for every deed ye do

I could match-out-match: am I not Afric's son,

Black of that black land where black deeds are done? (11. 2-7).

Addressing whites, the poet says: "Be not deceived"; the poet attempts to refute the whites' false belief that their evil powers are unmatched. The word "black" here not only means one of African origin, but it also means evil and wicked. McKay describes his black people as "almighty" and having the complete power to defy the white Americans: "But the Almighty from the darkness drew" (1. 8). The two paradoxical images of "darkness" and "light" represent McKay as a torch bearer guiding his people and revealing their suffering to the whole world:"My soul and said: Even thou shalt be a light / Awhile to burn on the benighted earth," (1l. 9-10). Even if the white racists impose their hegemony upon the American society, the word "awhile" denotes that their tyranny will not last forever; the black people will "prove" for the whole world that they have miraculous capability to destroy the despot whites. In the final couplet, the speaker compares "night" or darkness of African people to a huge monster which can swallow all white people; this image shows McKay's warning that death and ruin will be the inevitable destiny for the white supremacists:

Thy dusky face I set among the white For thee to prove thyself of highest worth;

Before the world is swallowed up in night,

To show thy little lamp; go forth, go forth! (1l. 11-14) 
McKay keeps stressing his radical attitude in his poems about the black-white conflict. He shows that African liberation cannot be attained without practicing violence against the white supremacists. The black masses have to defend mightily their human rights and not to be afraid of death. McKay's "If We Must Die" was inspired by the Red Summer of 1919. It appeared in the 1919 issue of the Liberator. During this summer, there was a rise in race riots, violence and hate crimes against the black community. The most violent events occurred in Washington, Chicago, Elaine, D.C and Arkansas. The term "Red Summer" was coined by James Weldon Johnson. The reasons behind the race riots of 1919 were racial prejudice, political corruption and exploitation of black voters, Newspaper lies about crimes of blacks, economic competition, police inefficiency and unpublished crimes against blacks. In this summer, hundreds of blacks died in at least thirty race riots. Jarette states that according to Barbara Foley, the Red Summer is "signifying at once the political repression of leftists and the bloody suppression of black rebellion" (qtd. in the introduction to A Long Way xxv). Amid the bloody riots of 1919, McKay wrote "If We Must Die" to express his political discontent. In the introduction to A Long Way, Jarrett states that McKay's most famous poem "If We Must Die" catapulted him into political and cultural stardom (xviii). He adds that it is considered as one of the best examples of the centrality of art to political action and incessant racial strife (xxv).

McKay's sonnet "If We Must Die" (Complete Poems 177-78) centers on African American fighting till death against the white enemies courageously. It is a desperate shout of defiance. Commenting on this poem, Smith claims that it reflects McKay's acrimony toward the lynchers of the blacks. The poem's message is "fight back, do not take a beating lying down" (273). Cooper notes that this poem brings McKay to the alert attention of the black world (301). Winston mentions that this poem is not only the rallying cry of oppressed peoples, but also a pillar of fire by night in many lands (45). Hickling claims that "If We Must Die" is forged in the crucible of racial lynchings and African resistance (22). The whole poem portrays a battle scene between blacks and whites. The speaker is a brave and noble leader inspiring his allies to fight honorably and heroically. He doesn't want his black people to die like "hogs" representing the strength, boldness, determination and bravery of Afro-Americans during their defense of themselves and their lives. The speaker uses the "dogs" metaphor to compare brutal and unjust white 
oppressors to vicious and fatal beasts denoting their inhumanity and savagery:

If we must die, let it not be like hogs

Hunted and penned in an inglorious spot

While round us bark the mad and hungry dogs,

Making their mock at our accursed lot." (11. 1-4).

McKay's more militant approach is seen in these two phrases "If we must die" and "O let us nobly die"; if death is the fate for his black warriors, they will die honorably and proudly and their blood will "not be shed" in "vain." Furthermore, the repetition of the phrase "If we must die" asserts that blacks must be willing to die for their rights of equality and freedom. McKay and the black Americans share a "common foe", namely the white oppressors: "O kinsmen! We must meet the common foe!" (1.9). Then, all black fighters shall gather and unite their energies as one man to end persecution of the white racists bravely: "Though far outnumbered let us show us brave, / And for their thousand blows deal one deathblow! / Like men we'll face the murderous, cowardly pack, / Pressed to the wall, dying, but fighting back!" (11. 10-14). The "men" versus "pack" is significant comparison; blacks are men ready to face, fight and defeat whites who are described as "cowardly pack." If blacks are defeated, they will come back one day to achieve victory and regain their own rights.

McKay shows that the black revolution against the ruthless racism paves the way for attaining African independence. He encourages AfroAmericans to start a violent revolution against racial injustice in his poem "We Who Revolt" (1925) (Complete Poems 208-209). The poet clearly aligns himself with writers who devote their art to the causes of their people. He is one of those artists who are committed to the "music of revolt". McKay says "We who make hymns, high music of revolt, / Who work at words like sailors at the ropes" (11. 21-22). The poet says that the black people do not care about "clothes or victuals". The fire image suggests that the poet's words charge people's hearts with the enthusiasm and vigor to change their position. The poet's words are also compared to "sickles" which are intended to remove delblitating ideas out of people's minds: "Our thoughts are tongues of fire, our words are sickles /To clear the jungle growth around man's mind." (11. 11-12). The aims of black revolution are not material gains only, they are "finer stuff"; the true targets of black revolt are freedom, justice and equality: "What can we gain-we who are consecrate / To realize a dream of finer 
stuff / Than comfortable sleep can generate? / To be sure rebellious selves: Is that enough?" (11. 13-16). McKay asks his people to respond rapidly to his radical "call". In the final couplet, McKay urges AfroAmericans to raise their "flags" of revolution against the oppressive white society:

Yet we must sound the call and onward press, For tyranny eternal must be fought,

No dreams we cherish of a perfect world -

But we posses our wills to do and dare,

Revolt with pennants streaming and with flags unfurled! (11. 34-35, 3840)

McKay wishes that his African people can defeat their white antagonists in a fatal combat. He shows his dream of revolutionary strife in which white unfairness must be encountered by black vehemence in his sonnet "Battle" (1920) (Complete Poems 144). As the notes to the poem point out, "Battle" is "commemorating a dream of revolutionary martyrdom and smoothly blending the duty of radical agitation with the pursuit of truth and beauty" (Complete Poems 307) .The speaker imagines lethal war between blacks and whites; the black crowds are "ruthless," tough, strict, sturdy and violent during their confrontation with their white enemies: "Last night I dreamed that in the deadly strife, / Where privileged power rules with ruthless might," (11. 1-2). McKay's heart is described as "rebellious" against barbarism of white persecutors. This deadly combat is not a choice; it must be the "duty" for all black people. And if blacks are martyred, they will gain the honor and glory of their great trial to liberate themselves. In the concluding lines, McKay confirms that only with a battle for black people's rights, blacks can live a dignified life in a world where "beauty," "truth", love, liberty and justice exist. Without dreadful strife, they will live in a despot society which will be ruled by white population:

The rhythmic beat of my rebellious heart.

So, I should have the grand end come to me,

While following the only way of duty

And questing for the soul of truth and beauty!

I'd go convinced that there could never be

A fairer life for truth or beauty's flower,

While earth is ruled by man's imperial power. (11. 8-14) 
McKay has ambivalent feelings towards America; he revolts against its racial inequality, but at the same time, he loves its energy and culture. In A Long Way, he says: "I desired to achieve something new, something in the spirit and accent of America. Against its mighty throbbing force, its grand energy and power and bigness, its bitterness burning my black body, I would raise my voice to make a canticle of my reaction" (9-10). McKay's sonnet "America" (1921) (Complete Poems 153) shows his determination to stand in strength against bigotry, prejudice and injustice in America. Smith states that "America" does not display McKay's bitterness. It gives advice to Afro-Americans to face squarely the tests and challenges that come to them as a persecuted minority (273). The speaker's hate-love relationship towards America leads him to rebel mightily against it. He detests America which is personified as a female that "feed[s]" him "bread of bitterness" of color distinction. It is also metaphorically compared to "tiger", symbolizing its hostility and vehemence towards black people. America is also personified as a thief that "steal[s]" Afro-American's joy, gaiety and life: "And sinks into my throat her tiger's tooth, / stealing my breath of life, I will confess" (1l. 23). The "bigness" of America sweeps the poet's being like a flood:

I love this cultured hell that tests my youth!

Her vigor flows like tides into my blood,

Giving me strength erect against her hate.

Her bigness sweeps my being like a flood (11. 4-7)

The speaker is brave and standing in confidence against the bigoted United States to break down the barrier of the color bar. America is compared to a building which has "walls" (racial barriers) : "Yet as a rebel fronts a king in state, / I stand within her walls with not a shred / Of terror, malice, not a word of jeer." (11. 8-10). The narrator presents the inevitability of destroying the American society in the future days at the hands of rebellious black people or it will eventually fade away in the same way that so many great civilizations were exposed to extinction through the passage of time:

Darkly I gaze into the days ahead, And see her might and granite wonders there, Beneath the touch of time's unerring hand, Like priceless treasures sinking in the sand (11. 11-14) 
McKay expresses his steadfast hatred and discontent towards racial discrimination in white America in his sonnet "The White City" (1921) (Complete Poems 162). Helbling states that in "The White City," McKay stressed not only his sense of alienation "but the irreducible basishatred upon which he achieved some sense of sanity and of his self's existence" (52). The title stands for New York in which white populations have the dominant power, while blacks are oppressed and strangled. The speaker's inner sentiments of hate and antagonism against white tyranny must be hidden from the American society because he lives on its land: "Deep in the secret chambers of my heart / I muse my life-long hate, and without flinch" (1l. 2-3). The speaker utilizes the contrasting colors of white and "dark" to display the depths of his rage against the white city and its tyrant rulers:

I bear it nobly as I live my part.

My being would be a skeleton, a shell, If this dark passion that fills my every mood, And makes my heaven in the white world's hell, Did not forever feed me vital blood. (11. 4-7)

A "skeleton" symbolizes death and mortality of black Americans due to the color bar and injustice committed against them. The two conflicting words "heaven" and "hell" indicate McKay's conflict and love/hate relation to America. He sees the chaotic picture of the city where darkness or "mist" is everywhere. The white city is "feed[ing]" him "vital blood" referring to the cruelty and barbarity of the white despotism. The adjective "vital" implies McKay's ambivalent feelings; the reasons behind his contradictory feeling are that he loves America because he lives in it, while he hates it because of bitterness of racism.

McKay's utilizing of fire imagery in his violent sonnets forcefully conveys his steadfast social protest. Sometimes, it refers to the powerful energy of destruction and purification. In McKay's sonnet "The Night Fire" (1922) (Complete Poems 178-79), he describes a scene of a city on fire at night. The personified fire is so powerful and spiteful that traditional methods used for fighting flames become useless. Dwellers of the city have a sense of regret, but they are helpless in the face of such angry fire that devours their city : "No engines shrieking rescue storm the night, / And hose and hydrant cannot here avail;" (11. 1-2). The fire is personified as laughing and mocking, denoting its ability of consuming the white racist society: "The flames laugh high and fling their 
The fire leaps out and licks the ancient walls

And the big building bends and twists and groans. (11. 5-6)

The poem's message is a threatening message intended to arouse feelings of fear and terror in whites, urging them to correct their mistakes before it's too late: "The watchers gaze, held wondering by the fire, / The dwellers cry their sorrow to the crowd," (11. 9-10). The repeated adjective "higher, higher" reinforces disablement of whites to turn off this vicious fire. Finally, this evil fire causes the fatal demise of the white persecutors:

The flames beyond themselves rise higher, higher,

To lose their glory in the frowning cloud,

Yielding at length the last reluctant breath.

And where life lay asleep broods darkly death. (11. 11-14)

McKay is a valiant insurgent and a mighty leader during his confrontation with apartheid and racial prejudice. He expresses his spirited and eloquent protest against injustice in the United States in his sonnet "The White House" (1922) (Complete Poems 148-49). In the notes to the poem in Complete Poems, it is said that Locke altered "The White House" to "The White Houses" in New Negro and to "White Houses" in Four Negro Poets, without consulting Claude McKay. Dr. Locke changed the title for political reasons as the original title is a direct reference to the White House in Washington, and that may be an issue against McKay's returning to America. The title does not mean the private homes of white people (309) ; it refers to the home of U.S. president. McKay compares himself, as a spokesman of the black race, to hard, strong, durable and resistant "steel" despite America's ill treatment, insult and contempt towards African Americans: "Your door is shut against my tightened face, / And I am sharp as steel with discontent;" (11. 1-2). McKay shows his bravery, intrepidity and fearlessness during his confrontation with inequitable white America; he cannot be conquered or defeated: "But I possess the courage and the grace / To bear my anger proudly and unbent." (11. 3-4). Then, he uses fire imagery to show the ability of African people to transform this enormous entity of the White House into ashes symbolizing annihilation of the white population: "The pavement slabs burn loose beneath my feet, " (1. 5). 
McKay's irritation is described as "savage" denoting black's practice of violence and force to gain their civil rights as American citizens. The fragile and delicate "glass" of "shuttered door" of the White House demonstrates that it can be easily broken; it stands for the simplicity and easiness of eliminating the color line. McKay says: "Deep in my wrathful bosom sore and raw, / And find in it the superhuman power/ [...] / Oh I must keep my heart inviolate, / Against the poison of your deadly hate!" (11. 10-11, 13-14). In spite of McKay's deep sadness and pain, he possesses the supernatural strength which enables him to get rid of the segregated laws of white America. The repetition of the modal verb "must" reveals the necessity and inevitability of black resistance against America's violation of black people's rights. America is metaphorically created as a snake which has "poison" referring to the danger of racism. But McKay is struggling against it.

In the American society, Afro-Americans suffered from job discrimination. Blacks worked most hours of the day with little rest and little wages. The white capitalists own the means of production. The black workers work but whites enjoy the profits of their work. The flaming revolt of the black working-class against capitalism is necessary to eliminate labor discrimination and exploitation and to achieve equality between all different classes in white America. In "The New Forces" (1922) (Complete Poems 150), McKay calls the proletariat (the black works) for struggling against the dictatorship of the capitalist system which is dominated by the white exploiters. "The New Forces" seems to be those challenging the old relations of capitalism. McKay says:

In everyplace, however high, they lurk.

In the great buildings where the pale youths clerk,

In ships and in the treasured pits of earth,

They stir the depths of men and come to birth.

I feel their mighty presence flaming near,

Oh, hark, my soul! Their voices everywhere. (11. 1-6)

Most of McKay's radical and racial poems are written in the form of the sonnet. The choice of the sonnet is intended to control his revolutionary sentiments within the restrictive form of the sonnet. Utilizing the Western literary form of the sonnet also allows McKay to prove his ability as a black writer to employ Western literary forms and to write literature equal in quality to the literature written by whites. In 
the introduction to Complete Poems, Maxwell states that one of McKay's poetic interests is to revive the sonnet as an instrument for radical persuasion. McKay is the first Afro-American poet "commended for investing elevated literary English and sonnet form with focused anger of the modern New Negro." His violent sonnets have dominated talk of his importance to Afro-American literature in the post- resistance era. He dragged the sonnet into the darkest corners of the twentieth century and propelled disciplined expressions of black rage and resistance into the main stream of African literature (xxi).

McKay's revolutionary passion infused the sonnet form, which usually tackles conventional themes like love, with rebellious sentiments. Maxwell adds that McKay's choice of sonnet clashed with his racial interest. His sonnets were traditional in form but racial in theme. So, "dealing with racial themes could make even a relentlessly traditional poet a kind of honorary modernist." The two-fifths of McKay's poems were written in the pattern of Petrarch and Shakespeare. Some critics flag his violent sonnets as successful modernizations of form through content (xxxv). When McKay limits his racial ideas in the context of sonnet, this makes him more distinctive than all Harlem poets. Smith claims that in the sonnet, McKay finds a verse form peculiarly adaptable to his ability and state. His talent is diversified, but this form seems the thing for thought which he wishes to convey to his readers (272).

The simplicity of McKay's language also allows his revolutionary message to reach easily to all different classes of people all over the world, whether they are elite or illiterate or literate, blacks or whites, without overcomplicating or overdramatizing. In the introduction to Complete Poems, Maxwell states that McKay "aimed for truthfulness, directness and naturalness" (xxxiii). McKay is more violent, militant, revolutionary and furious than other Harlem poets.

McKay considers himself as a guide and a messenger to his African people. He also sees himself as a torch bearer who can turn on the flaming fire of the black revolution. He refuses passive resistance; he calls for violent resistance to counter racial hatred, racial contempt, racial prejudice, oppression against blacks, evils of deprivation, the cruelty of whites and injustice.

As a major figure of the Harlem Renaissance, McKay is a spectacular figure in Afro-American literature. McKay is the foremost revolutionary poet of America. He succeeds in expressing the militant anger of a 
revolutionary black resistance. He drastically rejects racism and dehumanization by the white power. McKay also reveals an emphasis on celebration of blackness, racial pride and black identity. He is one of the first black writers to confirm African consciousness as a beneficial tool to awaken the exploited and oppressed race to have a confidence in its own culture, its own identity and to stand on equal footing with the white people. 


\section{Works Cited}

Baldick, Chris. The Concise Oxford Dictionary of Literary Terms. Oxford: Oxford University Press, 1990.

Boi, Paola. "Authors: 1-Overview." Wintz and Finkelman. Encyclopedia of the Harlem Renaissance, Vol.1.New York: Routledge, 2004. 64- 67.

Chauhan, P.S "Claude McKay: Polarities of the Colonial Imagination."Mcleod, A.L, ed. Claude McKay:

Centennial Studies. New Delhi: Sterling Publishers Private Limited, 1992. 22-31.

Cooper, Wayne. "Claude McKay and the New Negro of 1920s."Phylon, vol.25, No.3 (3rd Qtr. 1964),.297306.http://www.jstor.org/stable/273789.

Du Bois, W.E.B. The Souls of Black Folk, the Electronic Classics series, 2006.

Goldweber, David. "Home at last: The Pilgrimage of Claude McKay." Commonweal . 11-13.

Helbling, Mark. "Claude McKay: Art and Politics." Negro American Literature Forum, vol. 7. No 2 (summer 1973),49-52.http://www.jstor.org/stable/3041369.

Hickling, Frederick W. "Psycho-Historiographic Analysis of Claude McKay." Caribbean Quarterly, vol.38, No.1, Claude McKay (March 1992), 30.http://www.jstor.org/stable/40653802.

Jarette, Gene Andrew. Introduction. A Long Way From Home. By Claude McKay. New Brunswick, New Jersey and London: Rutgers University Press, 2007.

Jones, Sharon Lynette. "the Poetry of the Harlem Renaissance." Davis, Alex and Lee M. Jenkins, eds. The Cambridge Companion: to Modernist Poetry. New York: Cambridge University Press, 2007. 195-204.

Maxwell, William. Introduction. Complete Poems. By Claude McKay. New York: University of Illinois Press, 2004.

McKay, Claude. A Long Way From Home. Ed. Jarrette, Gene Andrew. New Brunswick, New Jersey and London:

Rutgers University Press, 2007.

---------------"Claude McKay Describes His Own Life: A Negro $\begin{array}{llllll}\text { Poet." Pearsona's Magazine [New } \quad \text { York], v. } & 38, & \text { no.3 }\end{array}$ (Sept. 1918), 275-

276.http://www.marxisthistory.org.

Complete Poems. Maxwell, William J, ed. New York: University of Illinois Press, 2004. 


\section{The Radical Poetry of Claude McKay}

"For A Negro Magazine." a 1934 circular reprinted in

Voices from the Harlem Renaissance, ed. Nathan Irvin Huggins

(New York: Oxford University Press, 1976) 403.

-"The Heart of a Constab," Constab Ballads (London:

Watts and Co, 1912).

Raynor, Deirdre J. "McKay: Examining Black Intellectuals and Expatriates." in Wintz, Cary D and Paul Finkelman, eds.

Smith, Robert A. "Claude McKay: An Essay in criticism."

Phylon(1940-1956), vol.9, No.3 $\quad\left(3^{\text {rd }}\right.$ Qtr., $\left.\quad 1948\right)$,

270- 273.http://www.jstor.org/page/info/about/policies/terms.jsp. 